\title{
き裂進展モデルに基づくはんだ疲労寿命予測方法*
}

$$
\text { 寺 崎 健*1, 谷 江 尚 史*1 }
$$

\section{A Method Based on a Crack Propagation Model for Predicting Solder Fatigue Life}

\author{
Takeshi TERASAKI*2 and Hisashi TANIE \\ *2 Mechanical Engineering Research Laboratory, Hitachi, Ltd. \\ 832-2 Horiguchi, Hitachinaka-shi, Ibaraki, 312-0034 Japan
}

\begin{abstract}
We previously developed a crack propagation model that can be uesd to calculate crack paths in micro-solder joints in semiconductor structures. We have now developed a method based on this model that can be used to predict solder fatigue life. Correcting for the effect of element size is difficult when fatigue life is calculated using a finite element method, so we investigated the dependence of the calculated life on the element size and developed a formula for approximating this dependence using Hutchinson-Rice-Rosengren singularity theory. This formula enables us to estimate fatigue life regardless of element size. We tested this formula by analyzing the effect of element size on the fatigue life of a center-cracked plate (CCP) made of tin-lead eutectic solder. The results agreed well with the experimental results, indicating that our method can effectively predict solder fatigue life.
\end{abstract}

Key Words: Life Prediction, Crack Propagation, Finite Element Method, Accumulated Damage, Solder

\section{1. 緒論}

近年，電子機器内の電子部品の急速な高密度実装 化に伴い，従来広く使われてきた TSOP（Thin Small OutlinePackage) や QFP (QuadFlat Package) 等のリード付 きパッケージに代わり, BGA（Ball Grid Aray）や CSP

(Chip Scale Package) 等のはんだバンプ実装パッケージ や，QFN（Quad Flat Nonleaded padkage）等のフラットリ ード構造のパッケージが増加してきており, はんだ接 続形状の多様化が進んでいる(1)。はんだ接合部の熱 疲労寿命は疲労き裂（以下，き裂と略す））進展の寄 与が大きいため, 従来のき裂発生寿命予測に基づく手 法では，はんだ接続形状による断線寿命の違いを扱う ことは困難である.

筆者らははんだ各位置に累積される損傷 ${ }^{(2)}$ に基づ いてき裂の発生や進展を評価することで, はんだ接続 部のき裂経路を解析的に再現できるき裂進展モデル

（以下，累積損傷モデルと記す））を考案し(3)，各 種はんだ接合部に適用した ${ }^{(4)} \sim(6)$. 本手法では算出 されるき裂准展寿命に要素寸法依存性があるが，その 補正方法として，異なった要素寸法の計算結果から真

\footnotetext{
* 原稿受付 2007 年 6 月 29 日.

*1 正員, (株) 日立製作所機械研究所(五312-0034 ひたちなか 市堀口 832-2).

E-mail : takeshi.terasaki.kq@ hitachi.com
}

の寿命を推定する方法を提案した ${ }^{(7)}$. しかし，この 手法では, 小さい要素寸法の計算結果が必要であるた め, 多大な計算時間を要することが問題であった.

そこで，本報では，OCP (Center-Cracked Plate) 試験 片を対象に, HRR（Hutchinson-Riœ-Rosengren）特異場理 論 ${ }^{(8)} \sim(10)$ に基づく二次元き裂先端のひずみ分布か ら，累積損傷量およびき裂進展寿命の要素寸法依存性 の理論解を求め, 理論解に基づく補正方法を導出した.

\section{2. 䍗䖽損偤モデル}

\section{2・1 アルゴリズム 既報 ${ }^{(3)}$ で考案した累積} 損傷モデルの概要を図 1 に示す．解析対象の中でき裂 発生を許容する領域を同一寸法の要素に分割し，各要 素に番号付けを行う. 次に, 各要素の損傷を表す関数 $f_{i}$ を初期值 0 とする. 関数 $f_{i}$ は各要素に損傷が累積され ることで増加し，值が 1 となったときにその要素が寿 命に至る (除去される) ことを示す関数である.ここ で, 添え字 $i$ は要素番号を示す. 次に, 温度サイクル 試験や機械的負荷試験を模擬した弾塑性応力解析を実 施して, 各試験 1サイクルあたりに各要素に生じる相 当塑性ひずみ $\varepsilon_{p q}^{i}$ を算出する. 次に, 各要素に生じる 塑性ひずみの值から，1 サイクルあたりに生じる損傷 量 $\Delta f_{i}$ を次式で算出する。 


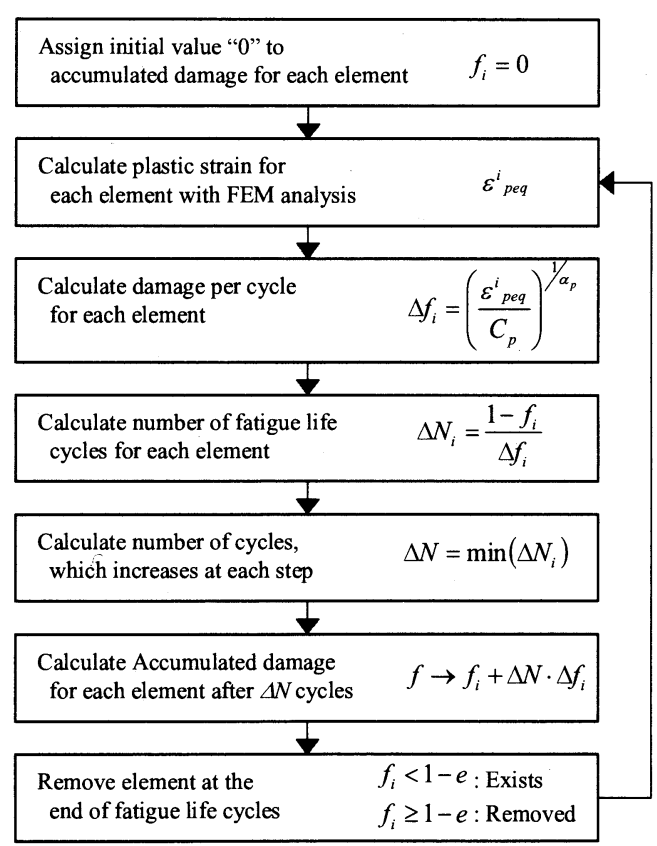

Fig. 1 Steps in method for predicting solder fatigue life

$$
\Delta f_{i}=\left(\frac{\varepsilon_{p e q}^{i}}{C_{p}}\right)^{1 / \alpha_{p}}
$$

ここで, $C_{p}, \quad \alpha_{p}$ は, 塑性ひずみ範井 $\Delta \varepsilon_{p}$ と低サイクル 疲労寿命 $N_{f}$ の関係を示す Coffin-Manson 則 ${ }^{(11)}{ }^{(12)}$ の 係数である.

$$
\Delta \varepsilon_{p}=C_{p} N_{f}^{-\alpha_{p}}
$$

次に, 求めた $\Delta f_{i}$ と各要素が既に受けている損傷 $f_{i}$ から, 各要素が寿命に至るために必要なサイクル数 $\Delta N_{i}$ を次式で算出する.

$$
\Delta N_{i}=\frac{1-f_{i}}{\Delta f_{i}}
$$

次に, 1 回の応力解析で増加させるサイクル数 $\Delta N$ を決定する. 応力解析はき裂が進展する毎に行う必要 があるので, 1 回の応力解析で増加させることができ るサイクル数は， $\Delta N_{i}$ が最も小さい要素が寿命に至 るまでのサイクル数である. したがって, $\Delta N$ は各要 素の $\Delta N_{i}$ の最小値となる. このとき, サイクル数が $\Delta N$ 増加することで各要素の損傷は次式の様に増加す る.

$$
f_{i} \rightarrow f_{i}+\Delta N \cdot \Delta f_{i}
$$

関数 $f_{i} か ゙ ~(1-e)$ 以上になった要素を除去して，形状を 変更した解析対象について再び応力解析を行う. e は 損傷が 1 に近い要素を消去するための定数で, 通常は 0.05 0.1 を用いる. 以降，上記手順を繰返すことで, 各要素に累積される損傷が線形累積損傷則 ${ }^{\text {(13) }}$ で評 価され，寿命に至った要素か順に除去される. よって, き裂経路が自動的に算出されるとともに, き裂准展寿 命が求められる.

非線形破壊力学によるき裂准展解析手法 ${ }^{(14)}$ と比 較すると, 提案手法は次の特長がある.

・初期き裂を仮定する必要がなく, 複数の疲労き裂の 進展経路を自動的に解析できる.

・疲労き裂准展に伴う有限要素解析モデルの変更が不 必要である.

- 1 回の応力解析で 1 つ以上の要素か消除されるサイ クル数の計算を行うので, 計算の絽返し数が少ない.

・疲労き裂准展特性を別途求める必要がなく, 既存の Coffin-Manson則の倸数を用いることができる.

このように，本解析手法は通常の応力解析と同様な容 易さで度労き裂准展が求められる大きな特長がある.

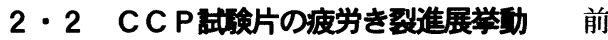
節で述べた累積損傷モデルのき裂進展寿命の要素寸 法依存性を検証するために, $\mathrm{Sn}-40 \mathrm{~Pb}$ はんだの CCP （Center-Cracked Plate）試験片による引張－圧縮負荷 の疲労き裂進展試験 ${ }^{(15)}$ を対象として, 計算を行 った.

図 2 に有限要素解析モデルの一例を示す. 対称性を 考慮して全体の $1 / 4$ を解析対象とし, 二次四角形平面 応力要素を用いて要素分割した. 検討した要素寸法は, $10 \mu \mathrm{m}, 25 \mu \mathrm{m}, 50 \mu \mathrm{m}, 100 \mu \mathrm{m}$ の4種類である. 有限要 素解析には社内で作製したソフトウェアを用いた.

Sn-40Pb はんだの応力ーひずみ挙動は，北野が円筒 試験片のねじり試験で測定したせん断の応力ーひずみ 関係 ${ }^{(16)}$ を, 単軸引張の応力ーひずみ関係に換算し

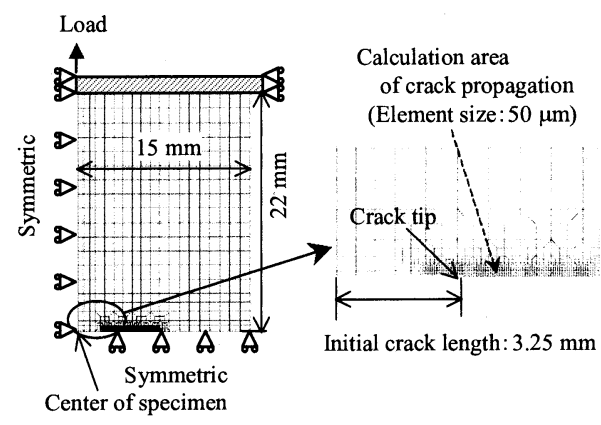

Fig. 2 FEM model for calculating crack propagation 


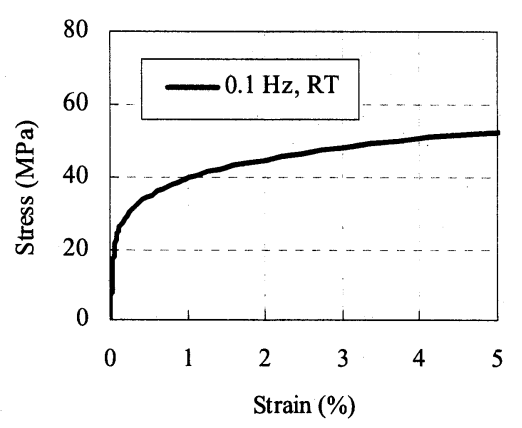

Fig. 3 Stress-Strain curve for $\mathrm{Sn}-40 \mathrm{~Pb}(0.1 \mathrm{~Hz}, \mathrm{RT})$

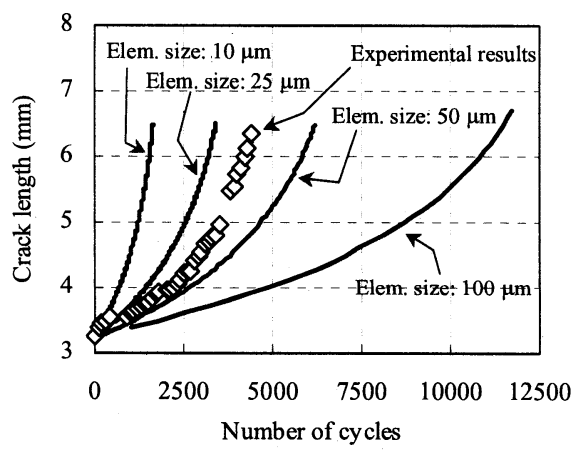

Fig. 4 Comparison of calculations and experimental results of crack propagation behavior in $\mathrm{CCP}$ specimen

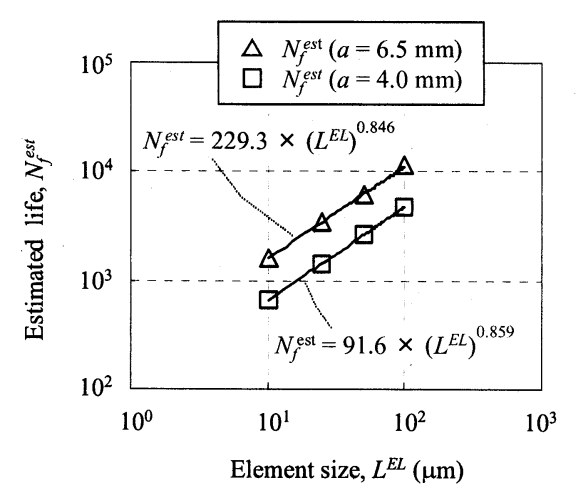

Fig. 5 Relationship between estimated life and element size

て用いた. このときミミーゼス型の相当応力ー相当塑 性ひずみ関係を仮定した. 円筒試験片の寸法は，外径 $15 \mathrm{~mm}$, 内径 $11 \mathrm{~mm}$, 全長 $75 \mathrm{~mm}$ (内, 掴み部長さ各 $15 \mathrm{~mm}$ ) である. 図 3 に後述の疲労き裂准展試験の条 件（繰返し周波数 $0.1 \mathrm{~Hz}$ ，室温）における応力ーひず み挙動を示す. Coffin-Manson 則の疲労延性俰数 $C_{p}$ およ
び疲労延性指数 $\alpha_{p}$ には, $\mathrm{Sn}-40 \mathrm{~Pb}$ のねじり疲労試験結 果 ${ }^{(16)}$ から算出した值 $\left(C_{p}=0237, \alpha_{p}=0.5\right)$ を用いた. 本試験のような引張一圧縮負荷の場合，OCP 試験片 のき裂先端では，引張時に大きな塑性ひずみが発生す るが, 圧縮時の塑性ひずみはき裂が閉口するため引張 時に比べて十分小さいと考えられる. そこで, 計算時 間の短縮のため, 疲労損傷の計算では, 疲労き裂の進 展には引張成分しか寄与しないと仮定し, 引張荷重を 負荷した時に生じる相当塑性ひずみを相当塑性ひずみ 範囲と近似した.

試験条件は荷重振幅 $1667 \mathrm{~N}$, 絽返し周波数 $0.1 \mathrm{H}$, 室温である. 図 4にき裂長さとサイクル数の関係の測 定值と計算値を示す. 測定值は, 要素寸法が $25 \mu \mathrm{m}$ で の解析結果と $50 \mu \mathrm{m}$ での解析結果のほぼ中間にあり, き裂進展挙動を大体再現できているが, 寿命の計算値 は要素寸法に大きく依存している.

本手法で得られる疲労き裂准展曲線は, 要素寸法 が大きくになるにつれて長寿命側に大きくずれていく. これは，損傷值の計算に相当塑性ひずみ範囲の要素平 均值を用いているためである. き裂先端のようなひず み勾配の大きいところでは, 要素寸法が大きいほうが 相当塑性ひずみ範囲の要素平均値が小さくなる.

図 5に, 計算で得られた予測寿命と要素寸法の関係 を示す. 予測寿命の定義は，き裂長さ $a$ が $4.0 \mathrm{~mm}$ に達 したサイクル数と, き裂長さ $a$ が $6.5 \mathrm{~mm}$ に達したサイ クル数の 2 種類とした. どちらの場合も, 両対数グラ フ上で直線関係を示し, 予測寿命は要素寸法の 0.85 0.86 乗に比例していた.

上述のように, 本手法の予測寿命は要素寸法に依存 するため, 定量的な予測寿命の算出には, 適切な要素 寸法を事前に，かつ簡便に調べる方法が必要となる. このような場合，理論に基づいた方法が望ましいと考 え，次章以降では，き裂先端の非線形特異場の理論解 である HRR 特異場モデルを用いて, 累積損傷量お よびき裂准展寿命の要素寸法依存性の理論解を求め, この理論解に基づく補正方法を導出した.

\section{HR R特買坦におけるき翌進展寿命}

\section{3・1 HR R特翼场 (14) 二次元き裂先端} 近傍の非線形特異場は, Hutchinson ${ }^{(8)}{ }^{(9)}$, Rice と Rosengren ${ }^{(10)}$ によって理論的に明らかにされ， HRR 特異場モデルと呼ばれている. 以下に, HRR 特異場モデルの概略を示す.

図 6に示す無限領域にある二次元き裂を仮定し，座

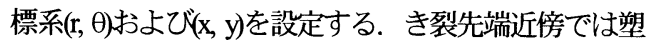




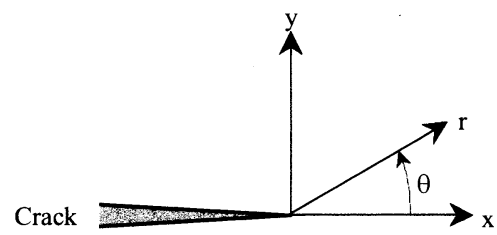

Fig. 6 2-dimensional crack in infinite area

性変形が支配的であると考えられるので，弾性ひずみ を省略して相当塑性ひずみ $\varepsilon_{p q}$ と相当応力 $\sigma_{q q}$ の非線形 関係を式(5)のべき乗則で近似する.

$$
\frac{\varepsilon_{p e q}}{\varepsilon_{0}}=\alpha\left(\frac{\sigma_{e q}}{\sigma_{0}}\right)^{n}
$$

ここで， $\alpha ， \sigma ， \% ， n$ は材料定数である. 式(5)に非 圧縮性条件と全ひずみ理論の比例負荷条件を適用し, 平面応力状態を仮定すると, き裂先端のひずみ成分 $\varepsilon_{i j}$ は，J積分を用いて次式の関数で表される.

$$
\varepsilon_{i j}=\alpha \varepsilon_{0}\left(\frac{J}{\alpha \sigma_{0} \varepsilon_{0} I}\right)^{\frac{n}{n+1}}: r^{-\frac{n}{n+1}} \cdot \widetilde{\varepsilon}_{i j}(\theta)
$$

ここで, $I$ は積分定数, $\widetilde{\varepsilon}_{i j}(\theta)$ は $\theta$ に依存する無次元

関数である. 式(6)からわかるように，HRR 特異場に おいて, $\mathrm{J}$ 積分はひず夕分布の拡大率としての役割を 持つ.

以上は，無限領域にある 2 次元き裂先端近傍での議 論であり，3 次元き裂を含む一般的なき裂形状に対し てはき裂先端の漸近解にすぎないが，材料挙動を式(5) でモデル化する限り，任意のき裂形状に対して近似的 に成立する.

3・2 相当塑性ひずみの要素寸法依存性 疲 労寿命の算出に用いる相当塑性ひずみ. $\varepsilon_{p e q}$ は次式で 定義される.

$$
\varepsilon_{p e q}=\left(\frac{2}{3} \varepsilon^{p}{ }_{i j} \varepsilon^{p}\right)^{\frac{1}{2}}
$$

式(の)のずみ特異場を仮定すると， $\varepsilon_{p q}$ は次式に示す $r$ と日の関数で表される.

$$
\varepsilon_{p e q}(r, \theta)=(J)^{\frac{n}{n+1}} \cdot r^{-\frac{n}{n+1}} \cdot E_{p e q}(\theta)
$$

き裂先端の相当塑性ひずみ分布の関数形 $E_{p q}(\theta)$ は理 論的に求めるのは難しいため, 本報では有限要素解析 を用いて求める.
累積損傷モデルでは，21 節で示したように，損傷 の算出に相当塑性ひずみの要素平均值 (以下, 要素平 均値と略す）を用いており, 要素平均値は積分点にお ける相当塑性ひずみの值を単純平均して求めている. 要素平均值 $\varepsilon_{p q}{ }^{\mathbb{E}}$ は, $k$ を積分点番号, $s$ を要素内の積 分点の数とすると, 次式で表される.

$$
\varepsilon_{p e q}^{E L}=\frac{\sum_{k}^{s} \varepsilon_{p e q}{ }^{k}}{s}
$$

最初に, 損傷が累積されていないき裂先端の要素に ついて考える. き裂先端から積分点までの距離 $r_{k}$ を, 要素寸法 $L^{E L}$ と定数 $R_{k}$ の積で表わし, 式(9)に式(8)を代 入すると, 要素平均値の要素寸法依存性が次式で表さ れる.

$$
\begin{aligned}
\varepsilon_{p e q}^{E L} & =(J)^{\frac{n}{n+1}} \cdot \widetilde{E}_{p e q} \cdot\left(L^{E L}\right)^{-\frac{n}{n+1}} \\
\widetilde{E}_{p e q} & =\frac{\sum_{k}^{s} R_{k}^{-\frac{n}{n+1}} \cdot E_{p e q}\left(\theta_{k}\right)}{s}
\end{aligned}
$$

すなわち, き裂先端要素の要素平均値 $\varepsilon_{p q}{ }^{E L}$ は, 要素 寸法 $L^{\mathrm{E}}$ の- $n /(n+1)$ 乗に比例する.

3 - 3 疲労寿命の要秦寸法依存性 式(10)の 相当塑性ひずみが相当塑性ひずみ範囲に等しいと仮 定すると, 1 サイクルあたりに生じる損傷量 $\Delta f_{i}$ の要 素寸法依存性は, 式(1)に式(10)を代入して次式で表 される.

$$
\begin{aligned}
\Delta f_{i} & =\left(\frac{(J)^{\frac{n}{n+1}} \cdot \widetilde{E}_{p e q} \cdot\left(L^{E L}\right)^{\frac{-n}{n+1}}}{C_{p}}\right)^{\frac{1}{\alpha_{p}}} \\
& =\left(\frac{(J)^{\frac{n}{n+1}} \cdot \widetilde{E}_{p e q}}{C_{p}}\right)^{\frac{1}{\alpha_{p}}} \cdot\left(L^{E L}\right)\left(\frac{-n}{(n+1) \alpha_{p}}\right)
\end{aligned}
$$

式(3)において， $f_{i}=0$ として，式(11)を代入することによ り, 損傷が累積されていないき裂先端の要素における 疲労寿命 $\Delta N_{1}$ の要素寸法依存性が次式のように求め られる.

$$
\Delta N_{1}=\left(\frac{(J)^{\frac{n}{n+1}} \cdot \widetilde{E}_{p e q}}{C_{p}}\right)^{-\frac{1}{\alpha_{p}}} \cdot\left(L^{E L}\right)\left(\frac{n}{(n+1) \alpha_{p}}\right)
$$

ここで, 要素寸法 $L^{E L}$ の $x$ 倍で規定される任意のき 裂長さ $a$ の区間において, $\Delta N_{1}$ が一定と仮定すると, き裂長さ $a$ を進展するのに必要なサイクル数 $N_{n d}$ は, 式(13)で表される. 


$$
\begin{aligned}
N_{n d}=\Delta N_{1} \cdot x=\frac{\Delta N_{1} \cdot a}{L^{E L}} \\
=a \cdot\left(\frac{(J)^{\frac{n}{n+1}} \cdot \widetilde{E}_{p e q}}{C_{p}}\right)^{-\frac{1}{\alpha_{p}}} \cdot\left(L^{E L}\right)\left(\frac{n}{(n+1) \alpha_{p}}-1\right)
\end{aligned}
$$

すなわち，累積損傷の影響を考慮しない場合，き裂長 さ $a$ を進展するのに必要なサイクル数 $N_{n d}$ は, 要素寸 法 $L^{E L}$ の $\left(n /\left((n+1) \cdot \alpha_{p}\right)-1\right)$ 乗に比例することになる.

累積損傷がある場合, 任意のき裂長さ $a$ を進展する のに必要なサイクル数は, 式(3)より次式で表される.

$$
N_{A D}=\sum_{i=1}^{x} \Delta N_{i}=\sum_{i=1}^{x} \frac{1-f_{i}}{\Delta f_{i}}
$$

き裂長さ $a$ の区間において, $\Delta f_{i}$ が一定 $(\Delta f)$ であると 仮定すると, 式(14)は次式に変形できる.

$$
\begin{aligned}
N_{A D} & =\frac{F}{x \cdot \Delta f} \\
F & =\sum_{i=1}^{x}\left(1-f_{i}\right)
\end{aligned}
$$

$\Delta f$ の要素寸法依存性は式(11)で示されている. F は, き裂が $a$ だけ進展するのに必要な全損傷量からき裂先 端以外で生じた累積損傷量を減じたもので，寿命に及 ぼす累積損傷の影響度を意味する. 累積損傷の要素寸 法依存性は，44節において具体例で検討する.

\section{C C P 試検片による解析的検佂}

\section{4・1 HR R特旺场の具体形 本章では, 2} 章で検討した CCP 試験片を対象に検討を行う。き 裂長さ $a$ が $4.5 \mathrm{~mm}$ の場合について, 式(8)に示した き裂先端の相当塑性ひずみ分布の関数形 $E_{p e q}(\theta)$ を有 限要素解析で求めた. 解析には, 式(5)の材料モデ ルを備えた汎用有限要素解析ソフトウェア ABAQUS/Standard ver.6.4.4を用いた. ABAQUS では 式(5)を次式の Ramberg-Osgood 型塑性モデルで記述 する.

$$
E \varepsilon=\sigma+\alpha\left(\frac{|\sigma|}{\sigma_{0}}\right)^{n-1} \sigma
$$

図 3 に示した $\mathrm{Sn} 40 \mathrm{~Pb}$ はんだの応力ーひずみ挙動より, 縦弾性係数 $E=26923 \mathrm{MPa}, \alpha=0.577, \sigma=24.5 \mathrm{MPa}, n=$ 5.9 とした. ポアソン比 $v$ は 0.3 を用いた. 式(5)の材料 定数のうち $\varepsilon_{0}$ は次式で表される.

$$
\varepsilon_{0}=\sigma_{0} / E
$$

図 7 に解析モデルを示す．半径方向の最小要素寸法は $2 \mu \mathrm{m}$ とした. 解析条件は，図4に示した試験と同じで ある.

$E_{\text {pad }}(\theta)$ は式(8)より, 次式で求められる.

$$
E_{p e q}(\theta)=\varepsilon_{p e q}(r, \theta) \cdot(J)^{-\frac{n}{n+1}} \cdot r^{\frac{n}{n+1}}
$$

有限要素解析で算出された $r=4,10,20,40,60 \mu \mathrm{m}$ 上にあ る節点の相当塑性ひずみ值を式(18)に代入して, 各 $r$ の $E_{p q}(\theta)$ を求めた（図 8). この場合の $\mathrm{J}$ 積分值は, 別途 ABAQUS で計算した $0.1539(\mathrm{~N} / \mathrm{mm})$ を用いた. 図 8

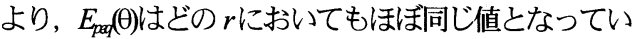
ることがわかる.ここでは, $r=10 \mu \mathrm{m}$ における $E_{p a d}(\theta)$ を5次多項式で近似した. 近似式を式(19)に示す.

$$
\begin{aligned}
\mathrm{E}_{\text {peq }}(\theta) & =-9.16 \times 10^{-13} \cdot \theta^{5} \\
& +4.30 \times 10^{-10} \cdot \theta^{4}-6.54 \times 10^{-8} \cdot \theta^{3} \\
& +3.15 \times 10^{-6} \cdot \theta^{2}-1.91 \times 10^{-5} \cdot \theta \\
& +4.72 \times 10^{-3}
\end{aligned}
$$

本報ではこの多項式を用いて，累積損傷モデルにおけ る相当塑性ひずみおよびき裂進展寿命の要素寸法依存 性を検討した。

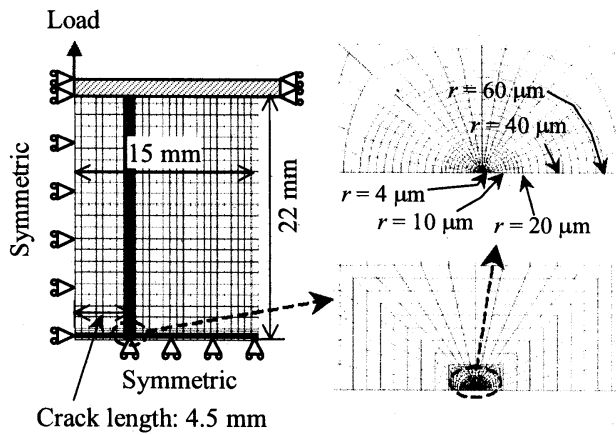

Fig. 7 FEM model for calculating HRR strain field

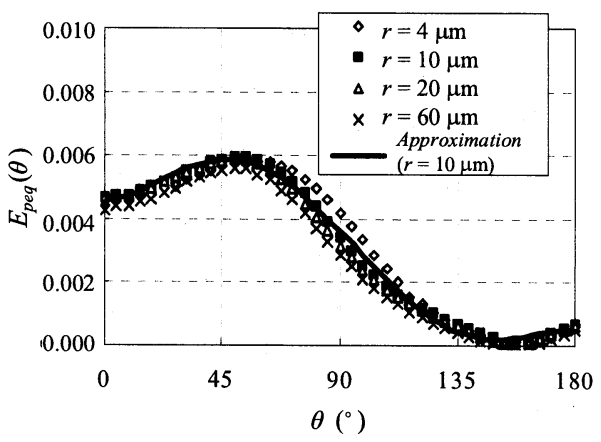

Fig. 8 Distribution of $E_{p e q}(\theta)$ 


\section{$4 \cdot 2$ き翌先端要秦のHRR 解 累積損傷} モデルでは, 3.2 節の式(9)で示したように, 相当塑 性ひずみの要素平均値を, 要素内の積分点における 相当塑性ひずみ値の単純平均として求めている.

前節で得られた HRR特異場の相当塑性ひずみ分 布 (式(8),(19)）を用いて, き裂先端要素の要素平均 值 ${ }_{p e q}^{E L}$ を式(10)から， $\Delta N_{1}$ を式(12)から計算した. 本 報では，以下，HRR解と記す．図9に計算に用い た要素の積分点位置 ${ }^{(17)}$ を示す. 検討した要素寸 法は, 2.2 節と同じ $10 \mu \mathrm{m}, 25 \mu \mathrm{m}, 50 \mu \mathrm{m}, 100 \mu \mathrm{m}$ で ある.

各要素寸法における $\varepsilon_{p e q}{ }^{E L}$ の HRR 解を図 10(a)に, $\Delta N_{1}$ の HRR 解を図 10(b)に示す. 本ケースでは $n=$ 5.9 を用いているので, 式(10)から明らかなように, HRRひずみは要素寸法 $L^{E L}$ の-0.855 乗に比例してい る. また, 式(12)から明らかなように, $\Delta N_{1}$ は要素 寸法 $L^{E L}$ の 1.71 乗に比例している.

4・3 き裂先端形状の影 HRRひずみで は，き裂は図7に示したような理想的なき裂を想定 していることになるが, 累積損傷モデルにおけるき 裂は, 図 2 に示したように, 要素寸法 $L^{E L}$ の高さを もつ長方形で近似される.このき裂形状の影響を確 認するために, 累積損傷モデルの有限要素解析モデ ルを ABAQUS/Standard で計算した. その結果を図 10(a)，(b)に併記した. 累積損傷モデルの結果

(ADM と記す） ) は, $\varepsilon_{p e q}^{E L}$ の場合, HRR解の下側 に位置し, 要素寸法 $L^{E L}$ の- 0.880 乗を示す. $\Delta N_{1}$ の場 合, HRR 解の上側に位置し, 傾きは 1.76 乗を示す. 累積損傷モデルにおいて, $\Delta N_{1}$ の要素寸法依存性は 式(12)にほぼ従っているが, 0.05 乗程度, 要素寸法 依存性が増えることがわかった.

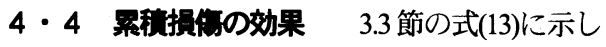
たように, 任意のき裂長さ $a$ を進展するのに必要な サイクル数 $N_{\text {urit }}$ は, 累積損傷の影響を考慮しない場 合, 要素寸法 $L^{E L} の\left(n /\left((n+1) \cdot \alpha_{p}\right)-1\right)$ 乗に比例する ことになる. 本ケースの場合, $n=5.9, \alpha_{p}=0.5$ であ るので, き裂先端形状の影響を考慮した場合では $0.76(=1.71-1+0.05)$ 乗となる. しかし, 図 5 に示し た計算結果では, 寿命 $N$ は要素寸法 $L^{E L}$ の $0.85 \sim$ 0.86 乗に比例しており, 0.1 乗の差がある. この差 の原因は累積損傷の影響と考え, 次のような考察を 行った.

これまで用いてきた初期き裂長さ $a=4.5 \mathrm{~mm}$ の解 析モデルにおいて, き裂が $100 \mu \mathrm{m}$ 進展したサイク ル数を寿命 $N_{100}$ として, HRR 解から各 $L^{E L}$ における $N_{l o 0}$ を計算した. き裂准展距離が $100 \mu \mathrm{m}$ と小さいた

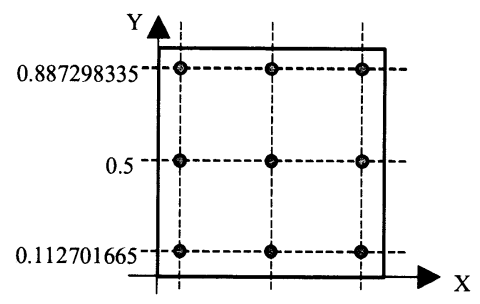

$\begin{array}{lll}0.112701665 & 0.5 & 0.887298335\end{array}$

Fig. 9 Position of integral point in element ${ }^{(17)}$

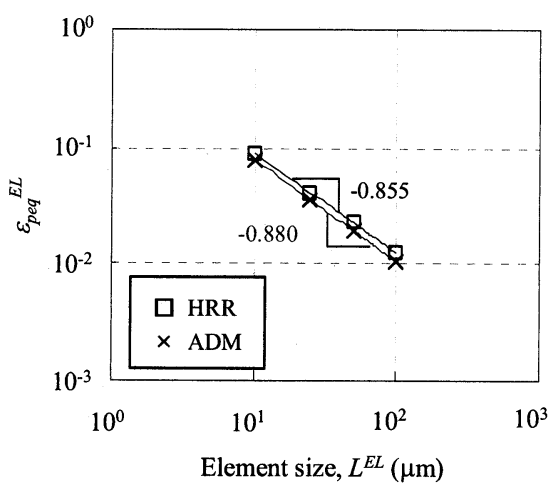

(a) Equivalent plastic strain

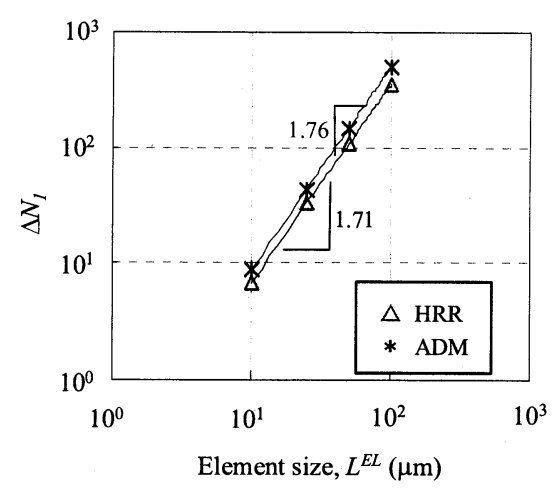

(b) Fatigue life

Fig. 10 Element-size dependence of crack-tip element

め,この範囲内では $\varepsilon_{p e q}^{E L}$ は変化しないと仮定した. 検討した $L^{E L}$ は, 前述と同じ $10 \mu \mathrm{m}, 25 \mu \mathrm{m}, 50 \mu \mathrm{m}$, $100 \mu \mathrm{m}$ である.

図 11 に $N_{100}$ と要素寸法の関係を示す. $N_{100}$ は $L^{E L}$ の 0.81 乗を示している. 累積損傷を考慮しない場 合の HRR 解は 0.71 乗であるので, 累積損傷の影響 は 0.1 乗ということになる. 前節で求めたき裂先端 


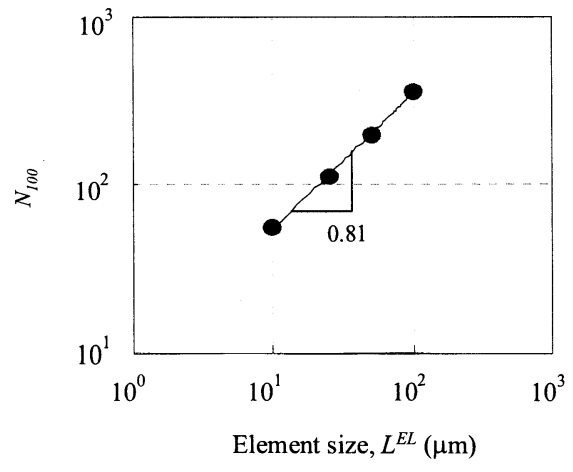

Fig. 11 Element size dependence of $N_{100}$ taking into account accumulated damage

形状の影響である 0.05 乗を加えると，寿命は $L^{E L}$ の 0.86 乗に比例することになり, 図 5 の計算結果とほ ぼ一致した.

\section{5. 要素寸法依存性の捕正方法}

ここまでの検討により，累積損傷モデルによるき裂 進展寿命は, 式(5)の材料定数 $n$ が 5.9 の場合, 要素寸 法の約 0.86 乗に比例することが理論的に明らかになつ た. しかし，この関係は，要素寸法が無限小に近づく と, 寿命がある一定值に収束するのではなく, 寿命も 無限小に近づくことを意味する. 実際の寿命は有限の 值であるので, 定量的な寿命算出に適した要素寸法が 存在するはずである. 図4 に示した計算結果では, 25 $\sim 50 \mu \mathrm{m}$ の間に適正な要素寸法が存在している.

図 12 に本報で提案する補正方法を示す. まず, 式 (2)の Coffin-Manson 則の適用限界と考えられる寿命 $N_{U L}$ を決め, そのときの塑性ひずみ範囲を, き裂先端要素 の相当塑性ひずみ範囲の適正值 $\varepsilon_{p o p}^{E}$ とする (図 12(a)). 本章で検討している COP試験片の場合, $N_{U L}$ は25とし たところ，き裂進展寿命が実験結果（図 4）に良く一 致した. この值が絶対的なものか, それとも各種条件 に依存するのかは，今後詳細に検討する必要がある.

続いて, 図 12 (b) に示す手順で適正な要素寸法を求 める. まず，寿命とするき裂長さを決定し，そのき裂 長さにおけるき裂先端の相当塑性ひずみ範囲の要素平 均値 $E_{\alpha \omega}$ ，求める. このとき計算に用いた要素寸法 を $L^{E}{ }_{a k}$ とする. き裂先端の相当塑性ひずみ範囲の要 素平均值 $\varepsilon^{E L}$ は, 式(10)より要素寸法 $L^{E L}$ の $(-n /(n+1))$ 乗に比例する. よって, 図 12 (a)で求めた き裂先端要素の相当塑性ひずみ範囲の適正値 $\varepsilon_{p p}$ を用 いて, 定量的な寿命算出に適正な要素寸法 $L_{p p}^{H}$ は次 式で算出することができる.

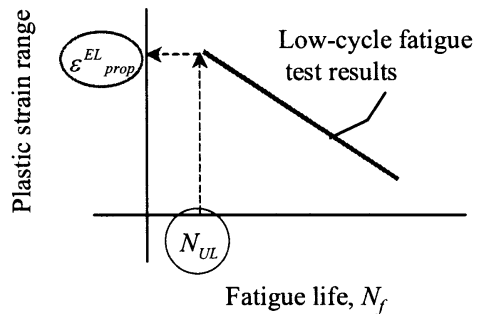

(a) Decision on upper limit of plastic strain range

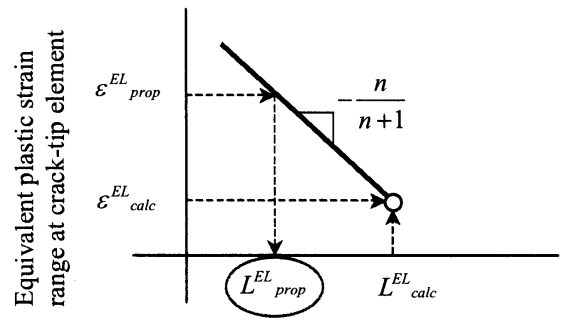

Element size, $L^{E L}$

(b) Calculation of proper element size

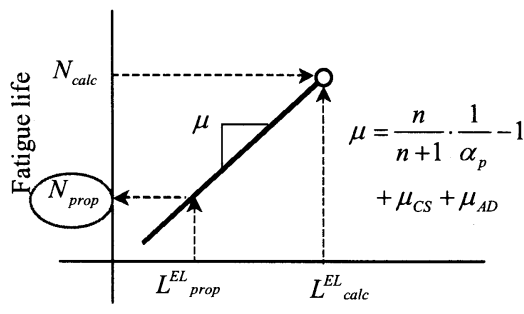

Element size, $L^{E L}$

(c) Fatigue life correction

Fig. 12 Procedure for fatigue life correction

$$
L_{\text {prop }}^{E L}=L_{\text {calc }}^{E L} \cdot\left(\frac{\varepsilon^{E L}{ }_{\text {prop }}}{\varepsilon_{\text {calc }}^{E L}}\right)^{\left(-\frac{n+1}{n}\right)}
$$

補正後の寿命 $N_{p q}$ は, 計算で算出された寿命 $N_{a k}$ と計 算に用いた要素寸法 $L^{E L}{ }{ }$ ，式(20)で求めた $L^{E L}{ }_{p p}$ を用い て, 次式で算出する (図 12(c)).

$$
\begin{aligned}
N_{\text {porp }} & =N_{\text {calc }} \cdot\left(\frac{L_{\text {prop }}^{E L}}{L^{E L}{ }_{\text {calc }}}\right)^{\mu} \\
\mu & =\frac{n}{n+1} \cdot \frac{1}{\alpha_{p}}-1+\mu_{C S}+\mu_{A D}
\end{aligned}
$$

$\mu_{\text {c以 }} 4.3$ 節で示したき裂形状の影響を示し，本ケース の場合の值は 0.05 である．また， $\mu_{40}$ は 4.4 節で示した 


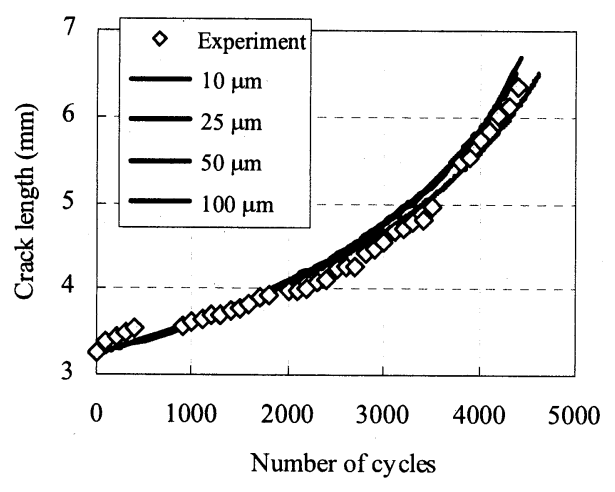

Fig. 13 Correction of calculated crack propagation life

累積損傷の効果であり, 本ケースの場合の値は 0.1 で ある.

この方法で図 4 に示した計算結果を補正した結果を, 図 13に示す.4種類の要素寸法の計算結果は，いずれ も補正により実験結果にほぼ一致している. 既存の手 法では, 3 種類以上の要素寸法の解析モデルを用いて き裂准展寿命を計算する必要があったが, 本提案手 法では 1 種類の要素寸法での計算結果だけで斉むため, 補正に要する時間が大幅に短縮できる.

\section{6. 結}

既報 (3) で提案した累積損傷に基づく疲労き裂進展 評価手法（累積損傷モデル）の実用上の課題であつた 算出寿命の要素依存性について, HRR 特異場理論に 基づく簡便な補正方法を検討した. 研究の結論を以下 に示す.

(1) HRR 特異場理論に基づく二次元き裂先端のひずみ 分布を仮定すると, 累積損傷モデルで算出される 寿命は, 要素寸法の $\left[n /\left((n+1) \cdot \alpha_{p}\right)-1+\mu_{C S}+\mu_{A D}\right]$ 乗に 比例することがわかった. ここで, $n$ ははんだの 応力ーひずみ挙動の材料定数， $\alpha_{p}$ ははんだの疲労 強度の材料定数, $\mu_{C S}$ はき裂先端形状の効果, $\mu_{4} D$ は累積損傷の効果である. 本解析事例の場合, $\mu_{\mathrm{c}} \mathrm{s}$ は約 $0.05, \mu_{4 D}$ は約 0.1 であった.

(2) 求めた寿命の要素寸法依存性の式から, 定量的な 寿命を簡便に補正する方法を提案した. まず，低 サイクル疲労寿命曲線から, き裂先端要素の相当 塑性ひずみの上限值を決定し, 寿命となるき裂長 さにおけるひずみ值から適正な要素寸法を求める. その後, 計算に用いた要素寸法と適正な要素寸法 との関係から，寿命を補正する.この方法により，
COP 試験片の疲労き裂進展挙動を補正できること を確認した.

\section{考文献}

(1) Japan Electronics and Information Technology Industries Association, Packaging technology road map in 2005 (in Japanese), (2005)

(2) Yasukawa, A, Simple Analysis of Thermal Fatigue Crack Propagation Behavior of Semiconductor-Chip-Bonding Solder Layers, Transactions of the Japan Saciety of Mechanical Engineers, Series A, Vol60, Na570, (1994),pp. 19-25

(3) Tanie, H. and Terasaki, T., Crack Propagation Model for Repoduction of Crack Paths in Micro-Solder Joints, Transactions of the Japan Saciety of Mechanical Engineers, Series A, Vol. 72,Na 717,(2006),pp.638-645

(4) Terasaki, T. and Tanie, H., Fatigue Crack Propagation Analysis for Micro Solder Joints with Void, Journal of Solid Mechanics and Materials Engineering, Vol. 1, No. 2, (2007)

(5) Tanie, H, Terasaki, T. and Naka, Y., A New Method for Evaluating Fatigue Life of Micro-solder Joints in Semiconductor Structures, Proceedings of Pacific Rim Technical Conference and Exhibition on Integration and Packaging of MEMS, NEMS, and Electronic Systems (IPACK05), (2005), IPACK2005-73331

(6) Köjma, K., Terasaki, T., Tanie, H, Fatigue Crack Propagation Analysis for Solder Joints in TSOP, General meeting of JSME Kanto branch (in Japanese), Vol 2005, No 11,(2005-3), pp. 389 390

(7) Tanie, H. and Terasaki, T., Fracture Life Evaluation of Solder Joints in Semiconductor Structures Using Crack Propagation Analysis, Transactions of the Japan Sociey of Mechanical Engineers, Series A, Vol. 73, №. 727, (2007),pp. 372-378

(8) Hutchinson, J. W., Joumal of the Mechanics and Physics of Solids, 16,(1968),pp. 13-31.

(9) Hutchinson, J. W., Joumal of the Mechanics and Physics of Solids, 16,(1968),pp. 337-347.

(10) Rice, J. R and Rosengren, G. F, Joumal of the Mechanics and Physics ofSolids, 16,(1968),pp. 1-12

(11) Coffm, LF, Jr, A Study of Cyclic-Thermal Stress in a Ductile Matal, Transactions of the ASME, 76(1954),931

(12) Manson, S. S.,Behavier of Materials Transactions, 1 (1970),805

(13) Miner, M A, Joumal of Applied Mechanics, Vol.12, (1962), A159 
(14) Yagawa, G, Fracture Mechanics (in Japanese), (1988) Baifukkan,pp. 177-182

(15) Terasaki, T., Kitano, M. and Mrura, H, Evaluation of Strain-ratodependent Fatigue-arack Propagation in $60 \mathrm{Sn} / 40 \mathrm{~Pb}$ Solder, Transactions of the Japan Society of Mechanical Engineers, Series A, Vol 66, No 648,(2000),pp.1506-1511

(16) Kitano, M, Kawai, S. and Shimizu, I, Thermal Fatigue Strength Estimation of Solder Joints of Surface Mount IC Packages,
Transactions of the Japan Society of Mechanical Engineers, Series A, Vol 54,No 505,(1988),pp. $1709-1715$

(17) Washizu, H. Handbook of Finite Element Method - basic edition -(in Japanese),(1981), Baifukan 